\title{
Identification and Research on Seismite in Drill Cores of Gulong Sag of Songliao Basin
}

\author{
Jiang Shengguo \\ ${ }^{1}$ Institute of Geology, Tianjin North China Geological Exploration Bureau, 300171 \\ andy-2006300480@163.com
}

Keywords: Gulong Sag, Seismite, Drill cores, Signal marks, Vertical succession.

\begin{abstract}
Based on the investigation of drill cores and surrounding geological setting, seismite is recognized in the first Member of Yaojia Formation of Cretaceous in Gulong Sag, and the vertical succession of seismite in the area is established. Several signal marks have been identified in seismite, such as liquefied sandstone dikes, micro-faults, seismic fissures, inconsistent rocks, load casts, eye-like structures etc. The discovery of seismite is not only a contribution to analyses on sedimentary environment and structural evolution, but also has a significant effect on reservoir-forming. seismic activity reduce the parameter of porosity and permeability, break up the better cap rocks, and the sandstone dikes, micro-faults and fissures vertically have a significant effect on the migration and accumulation of oil and gas.
\end{abstract}

\section{Introduction}

Seismite is of event deposit with seismic deformation [1], which develops mainly in the tectonical active areas such as rift valley and continental margin etc. Research on seismite started in 1988 in China, it was generally agreed that seismite was not a name of rock but represented the rock assemblage that had genetic relationship [2]. In recent years, many geologists discovered different kinds of seismites in regional geological surveys, and summed up different lithofacies types deposited by seismic events such as seismo-cataclasite, seismo-slump rocks and seismo-fold rocks and so on, which laid good foundation for the further investigations of seismo-catastrophic events and seismite [4]. Currently, publications of research on seismite in drill cores are rarely reported, and it usually is defined as the soft sediment deformation by many scholars. In this paper, deformations of unconsolidated and consolidated sediments from seismic response are studied systematically as the seismite, and the influences of seismic activities on reservoirs-forming for the specific conditions of research area are also discussed.

\section{Overview of regional geology}

Research area locates in the south of Gulong Sag of the northern Songliao Basin. Its southern and western boundaries are both constrained by the Nen River, east side connects with Daqing placanticline, north side to the north of West Putaohua oil field, and the total area of research area is about $3600 \mathrm{~km} 2$. The strata of Yaojia Formation in Gulong Sag become gradually thinner from south to north, and pinch out layer by layer from bottom to up. The southern is delta front facies sedimentary, and the northern belongs to delta plain facies sedimentary. Among them, the Putaohua reservoir is sedimentary sandy rocks of delta front facies with not only high porosity and high permeability sand reservoirs but also interbedded shale-bearing, calcium-bearing thin 
reservoirs, consisting of mainly reddish-brown sandy mudstone and gray-white siltstone. At present, seismite of Yaojia Formation has been found in drill cores of research area such as Yingtai-Da'an, Maoxing and Aonan etc. The signal marks of seismite are more apparent near the steep slope zone of Gulong Sag as a whole.

\section{Identification marks of Seismite}

Many geologist putted forward a number of special identification marks when they researched on the seismite in the outcrops, for example, liquefied dikes, micro-faults, seismic fissures, load casts and inconsistent rocks and so on[3], which have been discovered in the drill cores of Yaojia Formation in Gulong Sag..

\subsection{Liquefied sandstone dikes}

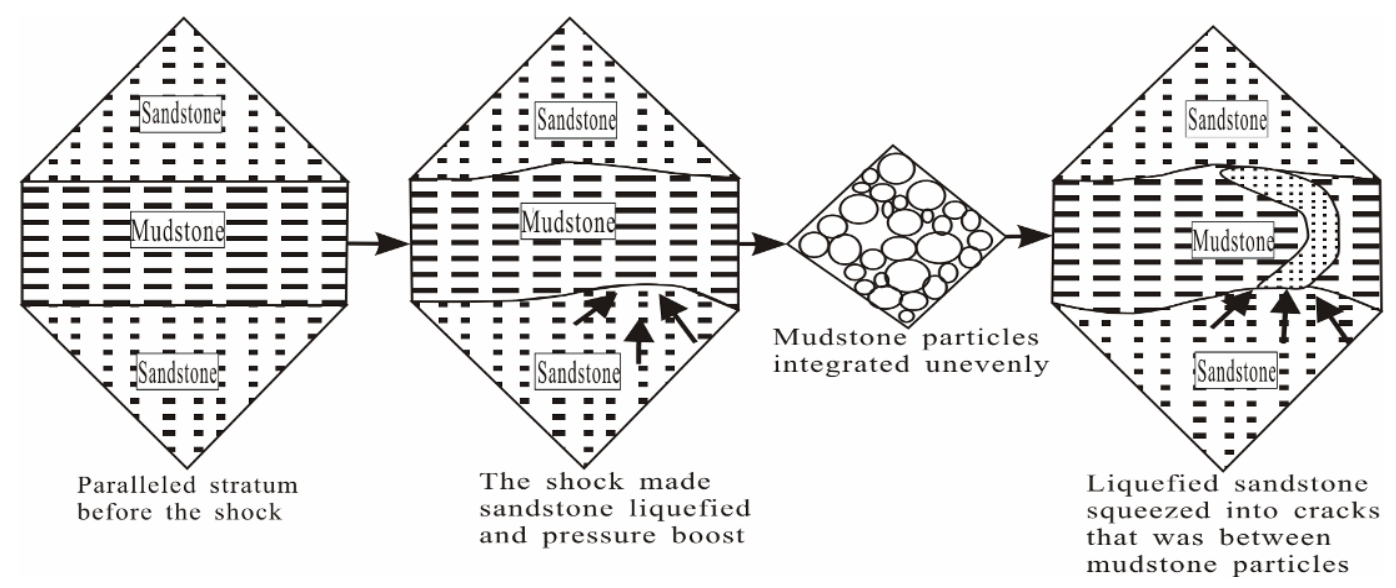

Fig. 1 Genetic sketch map of liquefied sandstone dikes

In the strata of research area, liquefied sandstone dikes are the most common structure of soft sediment deformation, which are mainly formed by light-colored fine sandstone squeeze into adjacent mudstone. Normally, the unconsolidated strata formed by fine sand and water are stable. When the earthquake happens, fine sand and water will change original arrangement pattern and are liquefied, then squeeze into the cracks of adjacent mudstone (Fig. 1). Such kind of sandstone dikes penetrate up and down into the country rocks with a close extension, varying in different size, the width of which ranges from $5 \mathrm{~mm}$ to $25 \mathrm{~mm}$, and divaricate upward. Generally, their tops vanish into the mudstone or connect with the above sandstone beds, and their bottoms connect with the underlying sandstone sediments. While penetrating the country rocks, the sandstone dikes often tend to bend so that present an irregular S-shape, especially, show the up-convex or down-concave (Plate I -1, 2), which are very similar to the liquefied sandstone dikes in continental faulted basins reported by Chen Shiyue, etc[5].

\subsection{Micro-faults and seismic fissures}

Micro-faults are formed by the shock of consolidated strata. Most of them belong to tensile faults, and can develop alone or show ladder-shape arrangement which is the most typical phenomenon. The ladder-shaped faults can be found at many points, and scale of faults is smaller. The extension of single fault is shorter, and is mostly between $0.5 \mathrm{~cm}$ and $5 \mathrm{~cm}$. The displacement of 
fault is mostly between $0.2 \mathrm{~cm}$ and $1 \mathrm{~cm}$, generally not more than $3 \mathrm{~cm}$. The angle of fault surface is relatively steep. Such faults are usually confined to develop inside strata (Plate I -3).

Seismic fissures are also formed by the shock of consolidated strata, which mostly develop in fine sandstone or fine sandstone with intercalation of thin-bedded mudstone. The occurrence of seismic fissures is steeper, the surface of fissures is straight, and the width is about $1 \mathrm{~mm}$. They can not penetrate up-and-down strata, but they can penetrate interlayer. Mostly, the fillings are fine sand. Sometimes such fissures can develop further into micro-grabens due to the action of vertical pressures [10] (Plate I -4). According to statistics, the width of top and bottom of micro-grabens are about $1.0 \mathrm{~cm}$ and $0.4 \mathrm{~cm}$ respectively, and with a depth of approximately $0.6 \mathrm{~cm}$. The thin-bedded dark mudstone (thickness of about $0.8 \mathrm{~cm}$ ) is usually developed in the lower part, and the interface is distinct.

\subsection{Load casts}

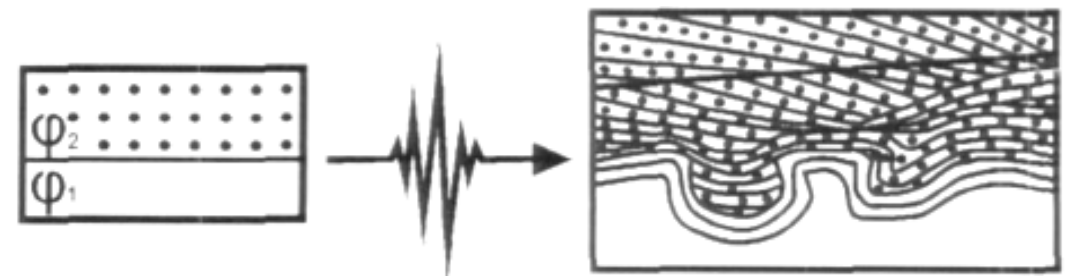

Fig. 2 Genetic model diagram of load casts (after Alfaro, et al., 1997) [6]

Formation of load casts as follows: in the later stage of seismic liquefaction, sediments contract volume in the process of land surface subsidence. Because the adjacent strata have different density contrast, overlying siltstone and fine sandstone sink into the soft argillaceous sediments under action of gravity caused by shock so that form the prominences (Figure 2), which ranging in size from several $\mathrm{mm}$ to several $\mathrm{cm}$ (Plate I -5). Characterized by fine grain and full of water, prominences occurred plastic deformation in the process of sinking so that show some irregular shapes such as chunky, spherical, pillow-like, drag and elongate, etc [7] (Plate I -6).

\subsection{Stratal rupture structures}

Stratal rupture structures are mainly characterized by rupture deformation. Because of seismic destruction, consolidated strata occurs cracks of $0.2-0.5 \mathrm{~mm}$ level, which are filled with fluids or gases in the later stage of liquefaction. Gradually, rocks on both sides of cracks are infected by fluids or gases so that the cracks show the width about $5 \mathrm{~mm}$. Such cracks intersect intricately in horizontal and vertical direction so as to cut rocks into pieces. So, the phenomenon found in the drill cores is created. They develop mostly in homogeneous fine sandstone and siltstone which have very good physical properties, usually coexist with seismic fissures, and have significant effect to reservoirs reconstruction (Plate I -7,8). Stratal fracture zone will be constructed, if large numbers of rupture structures occur in the horizontal direction. 


\subsection{Inconsistent rocks}

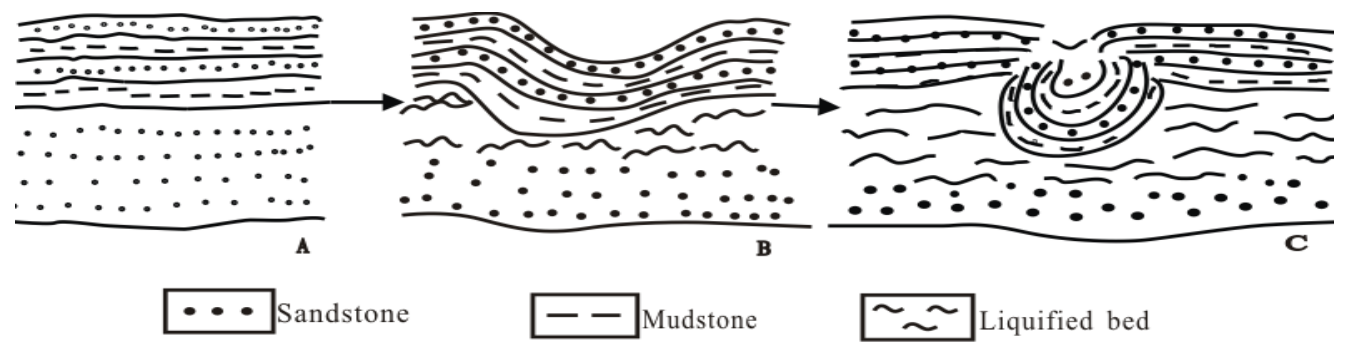

Fig. 3 Genetic sketch map of inconsistent rocks

When the liquefaction stops, sediments volumetric contraction occurs compressional force so that make strata appear sinking and fragmentation, based on which rocks that is inconsistent with country rocks are created (Fig 3), namely inconsistent rocks. Such rocks do not suffer from liquefaction, and only broken in the process of earthquake. They have definite boundaries and bedding that is consistent with country rocks. Inconsistent rocks develop mainly in siltstone and argillaceous siltstone, and ranging in size from $0.5 \mathrm{~mm}$ to $3 \mathrm{~cm}$. The shapes of rocks focus on sub-angular and angular, and sometimes appear rounding and bend. They can coexist with intra-stratal dislocation (Plate I -9, 10).

\subsection{Eye-like structures}

Eye structures are formed in the process of translating and rolling. The original slab-flaky and long strip feldspar continue to move and spin due to the influence of ductile and brittle-ductile deformation, both ends become rounder so that form the spheroid of eye-like, which is one of the most important structures of ductile and brittle-ductile shearing[8]. Such eye-like structures that are mainly formed by siltstone and mudstone are also developed in seismite. Eye-like structures found in the drill cores of research area can be divided into two types: firstly, dark mudstone is surrounded by siltstone; secondly, sandstone crams into the cracks of dark mudstone (PlateI-11, 12)

\subsection{Flocculent sand dikes}

Flocculent sand dikes are mainly found in multilayered thin interbeds of sandstone and mudstone. Mechanism of formation as follows: sand particles sink into the loose mudstone due to the influence of seismic action, meanwhile, the vertical force and horizontal force make sand particles vibrating frequently so that particles of different density sediment in different ways, and then the sand dikes liking flocculent are created (Plate I -13).

\section{Vertical succession of seismite}

According to the process of seismic action, vertical succession of seismite of Yaojia Formation in Gulong Sag is divided into five unites (from bottom to top): A, B, C, D, E (Table.1):

(1) Unit of seismic liquefaction(A): it represents the peak stage of seismic liquefaction, the main genesis is that the shock of hydro-plastic sediments and liquefaction in the process of earthquake, 
and it belongs to important and independent unit in vertical succession. Symbolic structure of this unit is liquefied sandstone dikes, which can pierce into the muddy intercalation in reservoir sand bodies so that promote the vertical heterogeneity of reservoir.

Table.1 Vertical succession of the Yaojia formation in Gulong sag

\begin{tabular}{|c|c|c|c|}
\hline $\begin{array}{l}\text { Active stage } \\
\text { of earthquake }\end{array}$ & Unit & Succession & $\begin{array}{l}\text { Main structures } \\
\text { and lithology }\end{array}$ \\
\hline Turbidity stage & $E$ & \multirow{5}{*}{ 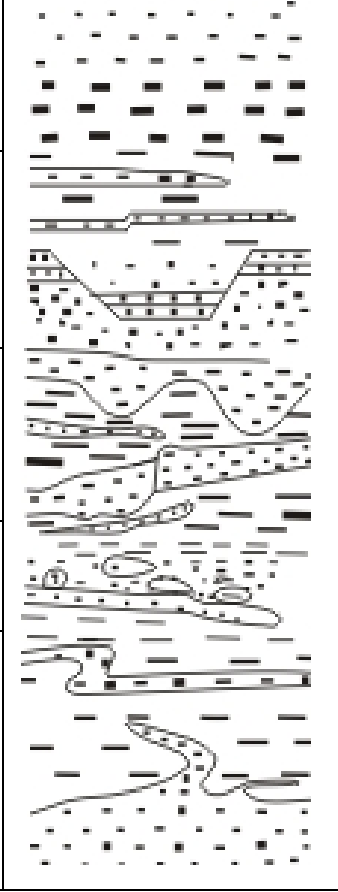 } & $\begin{array}{l}\text { Seismo-turbidite } \\
\text { Obvious normal grading }\end{array}$ \\
\hline Stop stage & $\mathrm{D}$ & & $\begin{array}{l}\text { Rupture structures } \\
\text { Micro-grabens } \\
\text { Seismo-cataclasite }\end{array}$ \\
\hline Decline stage & $\mathrm{C}$ & & $\begin{array}{l}\text { Load casts, Micro-faults } \\
\text { Inconsistent rocks } \\
\text { Seismo-slump rocks }\end{array}$ \\
\hline Transition stage & B & & $\begin{array}{l}\text { Flocculent sand dikes } \\
\text { Eye-like structures }\end{array}$ \\
\hline Peak stage & A & & $\begin{array}{l}\text { Liquefied sandstone dikes } \\
\text { Water-escape sand dikes }\end{array}$ \\
\hline
\end{tabular}

(2) Unit of semi-consolidated deformation(B): it represents the transition stage of seismic liquefaction, the main genesis is that the high-density sand particles suspending in pore water condense at some place, and develop mainly in the late stage of seismic liquefaction. Symbolic structures of this unit are flocculent sand dikes and eye-like structures, which can reduce the sand body connectivity so that increase the difficulty of exploration and development.

(3) Unit of load casts $(\mathrm{C})$ : it represents the decline stage of seismic liquefaction, and the main genesis is that the sinking of semi-consolidated sedimentary has a clear difference. Symbolic structures of this unit are load casts and micro-faults. Large-scale load casts and micro-faults can promote reservoir properties and are favorable for hydrocarbon migration.

(4) Unit of rupture strata(D): it represents the stop stage of seismic liquefaction, the main genesis is that the consolidated sediments occur rupture due to the influence of several forces, and develop mainly when the seismic liquefaction stops. Symbolic structure of this unit is rupture structures. Cracks and faults caused by rupture action can promote reservoir properties and hydrocarbon migration.

(5) Unit of seismo-turbidite(E): it represents the stage of allochthonous deposition, coexist with autochthonous (thickness of $3-15 \mathrm{~cm}$ ), and it has obvious normal grading. Slumping induced by seismic activity in the delta-front lead to the formation of fluxoturbidite, which will provide conditions for forming lithologic oil reservoir. 


\section{Conclusions}

(1) Seismite of Yaojia Formation in Gulong Sag develop mainly in the first Member. The repeated emergence of seismite in strata section shows that the movement of boundary faults has periodicity and episodicity. Generally, the closer some place distant from epicenter, the easier the place form seismo-cataclasite and seismo-cataclastic breccia, etc.

(2) Seismic succession is different in the different well area, and the integrated seismic succession is mainly developed in actic region of Gulong sag margin, which show that seismite is produced by earthquake that is caused by intense action of boundary fault. So, the discovery of seismite is conductive to identify the intense moving stage of basin-controlling boundary faults.

(3) Seismic activity can reduce the parameter for porosity and permeability of reservoirs in some well area; seismic activity is not only improve the reservoir capacity but also destroy the better cap rocks; sandstone dikes vertically, micro-faults and fissures have a significant effect to the migration and accumulation of oil and gas.

\section{References}

[1]. Seilacher A. General remarks about event deposits [M]. Marine Geology, 1982: 161-174.

[2]. Yang Jianping, Wang $\mathrm{Hu}, \mathrm{i}$, Chen Shiyue, et al. The features of seismite in Ji Yang Depression, Paleogene[J]. Acta Sedimentologica Sinica, 2004, 22 (2): 281 287.

[3]. Song Tianrui. A possible suit of seismo-tsunami sequence in Precambrian carbonate rock stratum in Shisanling in Beijing[J]. Chinese Science Bulletin, 1988, 38 (8): 609-611.

[4]. Zhao Chenglin. Fundamental principle of reservoir sedimentology[M]. Beijing: Petroleum industry press, 2001, 185 193.

[5]. Chen Shiyue, Yuan Wenfang, Yan Jihua. Discovery and significance of earthquake event deposits of early tertiary in the Ji Yang depression[J]. Chinese Journal of Geology, 2003, 38 (3): 377-386.

[6]. Alfaro P, MorettiM, Soria JM. Soft-sediment deformation structures induced by earthquakes (seismite) in Pliocene lacustrine deposits (Guadix-Baza Basin, CentralBetic Cordillera)[J]. Ecological Geologicae Helvetiae, 1997, 90: 531-540.

[7]. Du Yuansheng, G. SHI, Gong Yiming, et al. Permian soft-sediment deformation structures related to earthquake in the southern sydney basin, eastern Australia[J]. Acta Geologica Sinica, 2007, 81(4):511-518.

[8]. Liang Haihua, Liu Shuwen, Sun Xiaosong, et al. Analysis for Kinetics and Deformation of Porphyroblasts within Ductile Shear Zones and Numerical Modeling in Large Plastic Deformation[J]. Acta Scientiarum Naturalium Universitatis Pekinensis, 2000, 36 (1): 117-123.

\section{Explanation of plates:}

All pictures belong to the uniform scale.

1. Liquefied sandstone dikes of S-shape, Ying Well 86, and $1863.25 \mathrm{~m}$.

2. The sandstone dikes that squeeze vertically into the mudstone fissures, Ao Well 11, and $1855.60 \mathrm{~m}$.

3. Ladder-shaped micro-faults that arrange in parallel, Mao Well 23, and 1731.20m. 
4. Seismic fissures caused by tensile stress, and there are micro-faults, Mao Well 15, and $1743.53 \mathrm{~m}$.

5. Load casts, and there are rubbles below, Ying Well 62, and $1980.6 \mathrm{~m}$.

6. Load casts, which deform plastically because of seismic sink, Ying Well 36, and $2015.34 \mathrm{~m}$.

7. Stratal rupture structures, and there are seismic fissures and mudstone dikes of filling later, Mao Well 73, and 1759.0m.

8. Stratal rupture structures, and there are load casts above, Mao Well 202, and 1880.6m.

9. Inconsistent rocks, which have the same beddings with country rocks, Gu Well 682, and $1697.322 \mathrm{~m}$.

10. Inconsistent rocks, which sink into the mudstone and have the intra-stratal dislocation, Gu Well 144, and $1702.59 \mathrm{~m}$.

11. Eye-like structures, Da Well 36, and $1902.50 \mathrm{~m}$.

12. Eye-like structures, Ying Well 25, and $1835.0 \mathrm{~m}$.

13. Flocculent sand dikes, Pu Well 36, $1615.30 \mathrm{~m}$.

Plate I :

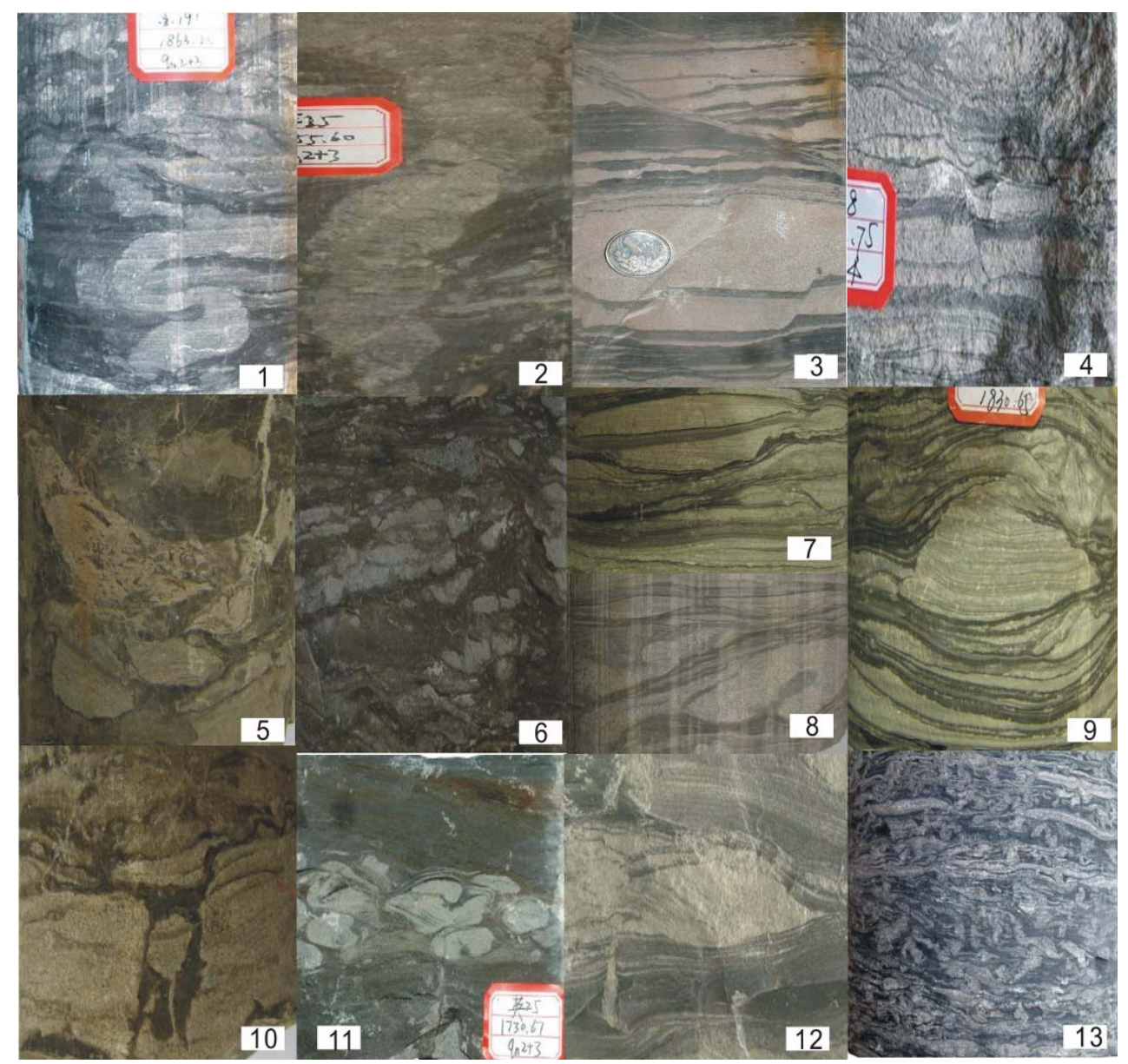

